\title{
Reply to the comment by M. Bouabdellah et al. on the paper "A late Triassic age for the EI Hammam high-REE fluorite deposit (Morocco): mineralization related to the central Atlantic magmatic Province?"
}

\author{
Alain Cheilletz • Dominique Gasquet • \\ Douglas A. Archibald
}

Received: 15 June 2010 / Accepted: 2 July 2010 / Published online: 20 July 2010

(C) Springer-Verlag 2010

Field, field, field... we acknowledge M. Bouabdellah, D. Banks and A. Klügel for reminding us that geology starts with strong field work. Alkaline-type rocks effectively do occur in the El Hammam district and have not been considered in our paper. However, the presence of lamprophyric dykes as mentioned by several authors cited by Bouabdellah et al. and their relevance for the fluorite mineralization must be considered with caution as:

- The attributed K-Ar age of $277 \pm 4$ Ma for these dykes may be biassed due to thermal overprint by the late Triassic magmatic event, as mentioned in our paper for the former published ages for the late-Variscan plutonic rocks in this area

- A connection of fluorite mineralization districts of western Europe with lamprophyric dykes was advocated by earlier authors as noticed in our paper (Hofmann and Schürenberg 1979, cited by Möller et al. 1984). However, a direct origin of the various components of the fluorite veins from the lamprophyric dykes remains hypothetical. The

Editorial handling: B. Lehmann

A. Cheilletz

ENSG-INPL, Nancy-Université and CRPG-CNRS UPR A2300,

BP 20, 54501 Vandoeuvre-lès-Nancy, France

D. Gasquet $(\bowtie)$

EDYTEM, Université de Savoie, CNRS UMR 5204,

73376 Le Bourget du Lac Cedex, France

e-mail: dominique.gasquet@univ-savoie.fr

D. A. Archibald

Department of Geological Sciences and Geological Engineering, Queen's University,

Kingston, Ontario K7L 3N6, Canada strong positive europium anomaly revealed by our analysis (Fig. 3; our paper) does not fit with the REE spectra of lamprophyres reported by Bouabdellah et al.

- In our study, the Ar/Ar age obtained for the fluorite mineralization is discussed in the frame of the spatial and temporal association with the Large Igneous Central Atlantic Magmatic Province. In that sense, TriassicJurassic basalts are never considered as providing the source of the fluorite mineralization but as a synchronous regional geodynamic marker of the anomalous heat flow driven by the extensional tectonics.

Dating, dating, dating... during pioneer work in Central Morocco, Cheilletz and Zimmermann (1982) militated 30 years ago for a systematic geochronological approach in the study of ore deposits. The radiometric data acquired by Mrini (1993) are the last ages available in this area. Therefore, the El Hammam fluorite-REE deposit needs much more reliable ages, particularly on the lamprophyric dykes, in order to present this deposit convincingly as another example of the alkaline-carbonatitic class of fluorite mineralizations, even if this remains a valuable working hypothesis.

\section{References}

Cheilletz A, Zimmermann JL (1982) Datation par la méthode K-Ar du complexe intrusif et des minéralisations en tungstène du Jbel Aouam (Maroc Central). CR Acad Sci Paris II:255-258

Möller P, Morteani G, Dulski P (1984) The origin of the calcites from $\mathrm{Pb}-\mathrm{Zn}$ veins in the Harz Mountains, FR of Germany. Chem Geol 485:91-112

Mrini Z (1993) Chronologie (Rb-Sr, U-Pb), traçage isotopique $(\mathrm{Sr}-\mathrm{Nd}-\mathrm{Pb})$ des sources des roches magmatiques éburnéennes, panafricaines et hercyniennes du Maroc. Unpublished Thesis. University of Marrakech, Maroc, $227 \mathrm{pp}$ 